\title{
USING AHP TO EVALUATE THE PERFORMANCE OF THE QUALITY, ENVIRONMENT, OCCUPATIONAL HEALTH AND SAFETY MANAGEMENT SYSTEMS
}

\author{
Helder Antônio da Silva* \\ Indústrias Nucleares do Brasil S.A. \\ Resende, RJ, Brazil \\ E-mail: heldersilva@inb.gov.br \\ Luiz Henrique Dias Alves \\ Amsted Maxion - Fundição e Equipamentos Ferroviários S.A. \\ E-mail: luizhenrique@amsted-maxion.com.br \\ Fernando Augusto Silva Marins; fmarins@feg.unesp.br \\ Messias Borges Silva; messias.silva@,feg.unesp.br \\ Ubirajara Rocha Ferreira; ferreiur@,feg.unesp.br \\ Sao Paulo State University (UNESP) \\ Guaratinguetá, SP - Brazil
}

\begin{abstract}
The paper analyses the application of the AHP method together with the attach A of ISO 9004:2000 in order to evaluate the performance of two industrial organizations, both possessing quality management systems with ISO 9001:2000 certifications, based on the specific requirements of quality, environment, occupational health and management systems. The evaluated organizations were a government-owned company from the science and technology sector that works in the nuclear area, and a private company that works in the automotive and railroad area. The open software WebHipre version 1.22 from Helsinki University of Technology, Finland, was used. By means of the sensibility analysis, it was possible to conclude that for the government-owned company, the most important criterion/requirement was related to product manufacturing with an index of 0.20 , and the most important subcriterion was related to production operations with an index of 0.048 , which represents the reality of the company. If the criterion/requirement index were increased by 0.03 , the most important subcriterion would be project and development. For the private company, the most important criterion/requirement was the management system with an index of 0.31 , and its most important subcriterion was document control with an index of 0.136 , which also represents the reality of the company. If the criterion/requirement index were decreased by 0.13 , the most important subcriteria would be suppliers and partners. The results demonstrated that the AHP is adequate to evaluate organizational performances. Both organizations presented similar performance levels.
\end{abstract}

Key Words: AHP, performance analysis, quality, environment, health management system

\section{Introduction}

Nowadays, the organizations have been searching incessantly for continuous improvement beyond the market evolution, which has demanded a better balance between human behavior and the productive systems. Some organizations have chosen to integrate their quality, environment, and health and safety management systems as a management strategic form or model with the purpose of surviving and improving their performance in the globalized market.

For Wilkinson and Dale (1998), the increasing interest in the environmental management systems based on the ISO 14001 norm, and in the occupational health and safety management system based on 
OHSAS 18001, by companies that have already implemented the ISO 9001 quality management system, lead these companies to search in the structure, in the principles and the specific characteristics of these norms and specification, the common elements with the purpose of integrating these management systems.

The Integrated Management lines up the Quality Management Systems (ISO 9000), Environmental (ISO 14000), Occupational health and safety (OHSAS 18000) and in some cases it also includes the Social Responsibility (SA 8000). (Cerqueira, 2006; Corrêa, 2004; De Cicco, 2003; Jorgensen, 2006; Karapetrovic, 2002; Wilkinson, 1999).

Therefore, in the competitive context, a global evaluation is part of company management activities; although evaluating globally and systematically is a complex task. An evaluation can guarantee activity control in strategical, managerial or operational levels of a company, and it also has the purpose of assuring decision making based on information and observation facts.

Hence, in an evaluation, the difficulties begin with the definition of which criteria/items are to be examined and which method will be used. These criteria are normally chosen based on the legislation concerning the subject; the methods, on the other hand, are chosen by observation and assays. In this context, the criteria vary according to the relevant area (quality, environment, health and safety). Such variety of evaluation criteria/items demands an understanding of the organic interrelation of the concepts in the three areas (quality, environment and, occupational health and safety) until it constitutes a unit formed with the proposals of each area.

Recent researches observe that the AHP method allows an evaluation of each criterion/item importance in relation to the considered context rationally and precisely. Because of these attributes, the application of the AHP method is a trustworthy alternative for this research.

According to Gomes et al. (2004), one of the first methods developed in the multicriteria decision making environment, and perhaps the most used in the world, is the Analytic Hierarchy Method, best known as the AHP method, created by Prof. Thomas L. Saaty in 1980. In this method, the decision making problem is divided in hierarchical levels, making its understanding and evaluation, therefore, easier.

The AHP method (Analytic Hierarchy Process) has been used for situations such as: priority definition, cost-benefit evaluation, allocation of resources, performance measurement (benchmarking), marketing evaluation or research, requirements determination, strategic decisions (Forward \& Backward Planning), activities sequence planning, forecasting, negotiating and conflict resolution, social or political division and forecast, and analysis of decision under risk. (SHIMIZU, 2006).

For Gomes et al. (2004), the AHP method, after dividing the problem in hierarchic levels, determines, clearly and through the synthesis of agent decision values, a global measure for each alternative, prioritizing or classifying them as the method is finished.

Forman and Selly (2001) argue that the name of the AHP method explains its application logic:

- Analytic: Because of its characteristics, the AHP should be called Hierarchic Synthesis Process since in its essence the AHP assists in the measurement and sintetization of a series of factors involved in complex decisions;

- Hierarchy: Subdivision in hierarchy is a known characteristic to organizations. Hierarchy is the adaptable way of finite intelligence to assume a complex situation. Great organizations possess hierarchic structures as they are divided in units that are subdivided in smaller units and so on;

- Process: A process is a series of actions, alterations or functions that leads to an end or result. The process of the AHP is not a model in which the correct answer is found, but a process that helps decision makers find the best answer.

For Forman and Selly (2001), the AHP method makes the decision maker consider perceptions, experiences, intuitions and uncertainties in a rational way, generating levels of priorities or weights. It 
is a compensatory decision making method since fragile alternatives for a certain objective can have strong performance for others.

The comparison pair for the alternatives is carried through using a proper scale, which varies from 1 to 9. This scale, called the Basic Scale, was proposed by Saaty together with AHP method in 1980. According to Luz et al. (2006), for a level with $n$ criteria, $n(n-1) / 2$ comparisons are required between $[[a]]_{i}$ and $[[a]]_{j}, \forall i, j$, constructing a preferences matrix $C_{i, j}(n \times n)$. The comparison is made by answering the following questions:

- When influencing the level above, the criterion $[[a]]_{i}$ is more important than, less important than or as important as criterion $[[a]]_{j}, \forall i, j$;

- For nonequivalent $[[a]]_{i j}$, being that $[[a]]_{i}$ is more important than $[[a]]_{j},[[a]]_{i}$ is: (i) a little more important than $[[a]]_{j}$; (II) much more important than $[[a]]_{j}$; (III) very strongly more important than $[[a]]_{j}$; or (IV) absolutely more important than $[[a]]_{j}$.

The preference matrix is filled according to Picture 1. Intermediate values are destined to intermediate situations, in which it is necessary to discern more clearly between two very similar alternatives, according to judgment criterion.

Picture 1: Preference options based on paired comparisons

\begin{tabular}{|c|c|c|}
\hline $\begin{array}{l}\text { Intensity of } \\
\text { Importance }\end{array}$ & Definition & Explanation \\
\hline 1 & Equal Importance & Two activities contribute equally to the objective \\
\hline 2 & Weak or slight & \\
\hline 3 & Moderate importance & $\begin{array}{l}\text { Experience and judgment slightly favor one } \\
\text { activity over another }\end{array}$ \\
\hline 4 & Moderate plus & \\
\hline 5 & Strong importance & $\begin{array}{l}\text { Experience and judgment strongly favor one } \\
\text { activity over another }\end{array}$ \\
\hline 6 & Strong plus & \\
\hline 7 & Very strong or demonstrated importance & $\begin{array}{l}\text { An activity is favored very strongly over another; } \\
\text { its dominance demonstrated in practice }\end{array}$ \\
\hline 8 & Very,very strong & \\
\hline 9 & Extreme importance & $\begin{array}{l}\text { The evidence favoring one activity over another } \\
\text { is of the highest possible order of affirmation }\end{array}$ \\
\hline $1.1-1.9$ & $\begin{array}{l}\text { When activities are very close a decimal } \\
\text { is added to } 1 \text { to show their difference as } \\
\text { appropriate }\end{array}$ & $\begin{array}{l}\text { A better alternative way to assigning the small } \\
\text { decimals is to compare two close activities with } \\
\text { other widely contrasting ones, favoring the larger } \\
\text { one a little over the smaller one when using the } \\
1-9 \text { values. }\end{array}$ \\
\hline $\begin{array}{l}\text { Reciprocals of } \\
\text { above }\end{array}$ & $\begin{array}{l}\text { If activity } i \text { has one of the above nonzero } \\
\text { numbers assigned to it when compared } \\
\text { with activity } j \text {, then } j \text { has the reciprocal } \\
\text { value when compared with } i\end{array}$ & A logical assumption \\
\hline $\begin{array}{l}\text { Measurements } \\
\text { from ratio scales }\end{array}$ & & $\begin{array}{l}\text { When it is desired to use such numbers in } \\
\text { physical applications. Alternatively, often one } \\
\text { estimates the ratios of such magnitudes by using } \\
\text { judgment }\end{array}$ \\
\hline
\end{tabular}

Source: Saaty (2008)

Once the preference matrix is filled, the calculation of the relative importance of criteria is performed, and the autovectors with the biggest autovalues of the matrix are then found. The components of the autovectors are the criteria priorities and the value attributed to autovector will be the level of coherence judgment, within the bases proposed by the method. Being [[A]] the comparison matrix, the priority vector $\mathbf{w}$ is, then, calculated in a way that it satisfies the equation (1), and the coherence reason $\mathrm{CR}$ is calculated by the equation (2).

$$
\text { A.w }=\lambda_{\max } \cdot \mathbf{w}
$$




$$
\mathrm{CR}=\left[\lambda_{\max }-n\right] /[\mathrm{RI}(n-1)]
$$

Where: $n$ is the number of criteria; $\lambda_{\max } \leq n$ is the biggest autovalue, and R.I. is the average random coherence index, extracted from the simulation Table with samples matrices of various dimensions. Picture 2 shows R.I. values related to $n$ :

Picture 2: Random coherence index

\begin{tabular}{|c|c|c|c|c|c|c|c|c|c|c|c|c|c|c|c|}
\hline Order & 1 & 2 & 3 & 4 & 5 & 6 & 7 & 8 & 9 & 10 & 11 & 12 & 13 & 14 & 15 \\
\hline R.L. & 0 & 0 & 0.52 & 0.89 & 1.11 & 1.25 & 1.35 & 1.40 & 1.45 & 1.49 & 1.52 & 1.54 & 1.56 & 1.58 & 1.59 \\
\hline First Ordider Differenoes & & 0 & 0.52 & 0.37 & 0.22 & 0.14 & 0.10 & 0.05 & 0.05 & 0.04 & 0.03 & 0.02 & 0.02 & 0.02 & 0.01 \\
\hline
\end{tabular}

Source: Saaty (2008).

Saaty (2001) and Salomon (2004) recommend that, for CR vectors above 0.20 , the judgments should be reviewed; however, such incoherence must serve more as an alert than as an undesirable event. Therefore, the review of judgments is a systematic procedure of improved aid to the decision.

For the present work, a 0.20 index for verifying the coherence judgments will be used, as described in the previous paragraph.

It is important to examine how sensitive the preferred alternative is as for changes in the judgments emitted by the decision maker. Therefore, in order to apply the AHP method in this work, the free software Web-Hipre, version 1.22 by the University of Helsinki in Finland, was used; it allows the performance of dynamic sensitivity analysis, and is able to modify the elements weights of a certain hierarchy level, being possible to observe alterations in the alternatives punctuations.

\section{Elaboration of the proposed method}

\subsection{General considerations}

The method consists of evaluating the performance of quality management, environmental and occupational health and safety systems integrated, at the strategical, managemental and operational levels. It involves organizations that are implementing or have already implemented these integrated systems or not by means of preestablished criteria.

The evaluation will be executed by people involved with management systems, such as coordinators, managers and technical assistant who will be instructed by the researcher to solve question when necessary. The people involved with management systems in general will need to have knowledge of the areas and norms of the evaluated management systems.

To elaborate the proposed method, the bibliographical survey of the subject was considered. It was based mainly on the AHP method and the self-evaluation method of annex of ISO 9004:2000. 


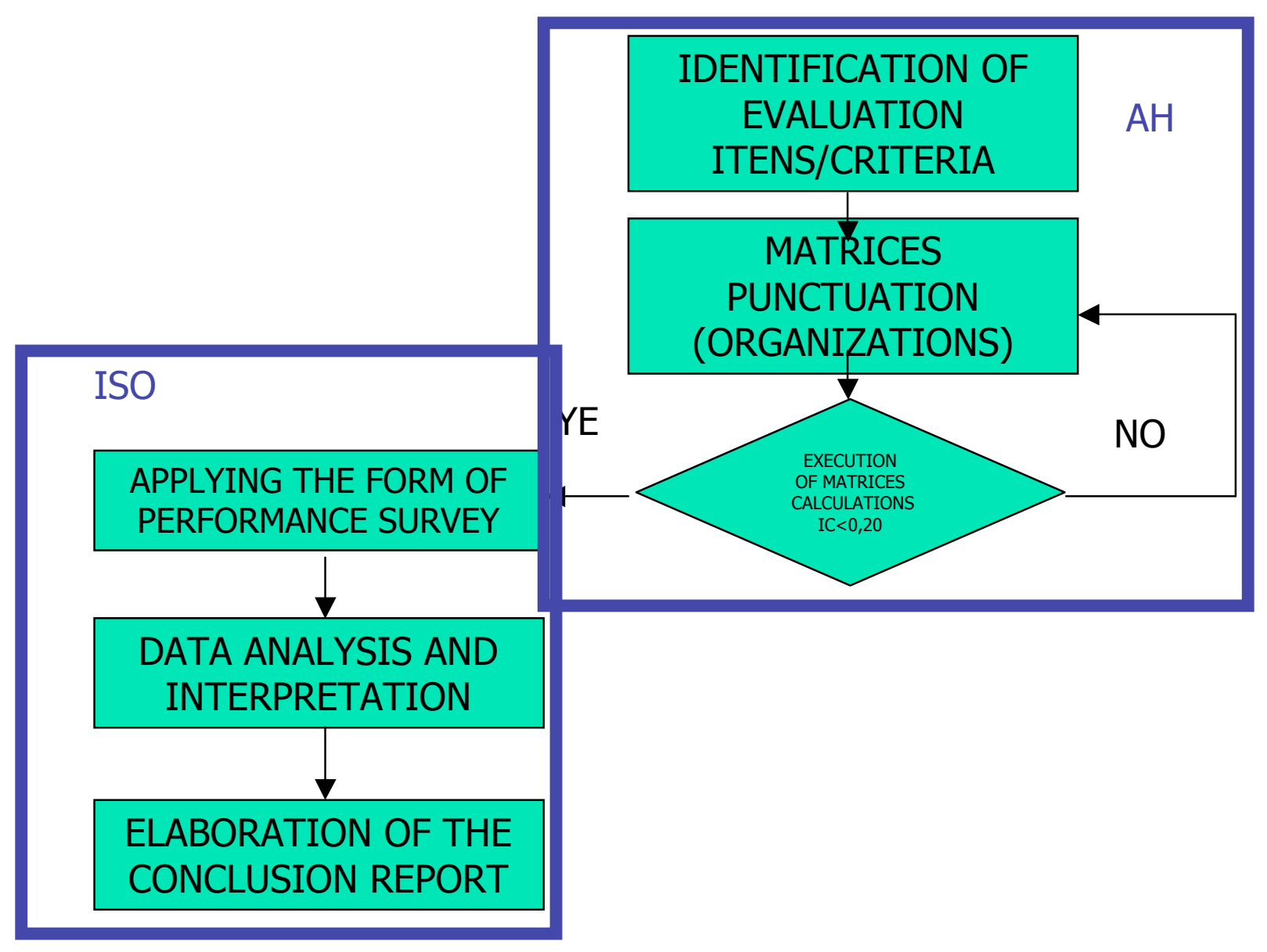

Figure 3: Main phases of the proposed method

\subsection{Description of method phases}

\subsubsection{Phase 1: identification of evaluation itens/criteria}

The items/criteria identification is a unique phase of the method, that is, once the items/criteria are identified by the researcher, this will no longer be executed during the application of the proposed method in the organizations. This identification is based on bibliographical survey presented in chapter 2. Through the conclusion of this phase, a requirement hierarchic structure to evaluate the importance of these requirements for the performance of the evaluated organization is obtained.

\subsubsection{Phase 2: matrices punctuation}

This phase is performed in the organizations by the people involved with quality, environment and occupational health and safety management systems, or a team that implemented it or is responsible for the maintenance of the integrated management system.

In this phase, the peer evaluation of the hierarquic structure requirement resulting from phase 1 is performed with the form and in agreement with the AHP method procedure. Such evaluation can be performed in two ways:

- through a meeting with the team and the researcher, the punctuation is given through a consensus of the people in the team; or

- through the distribution of a punctuation form to the team, each member will evaluate and mark each requirement level of importance in the form. The form is returned to the researcher for calculations and analyses. 


\subsubsection{Phase 3: execution of matrices calculations}

The calculations of the matrices are performed in agreement with the AHP method procedure; the results are the local priorities and coherence indices for each judgment matrix. In the cases where the forms were distributed, the filling of the matrices with the values of judgment will be performed by the geometric average of the values attributed to the forms.

When the coherence index of a matrix is bigger than 0.20 , the necessity of remaking this matrix judgment or the calculations of local priorities should be evaluated.

\subsubsection{Phase 4: applying the form of performance survey}

In this phase the form for surveying the performance of the organization will be applied in the organizations and it can be carried out in two ways:

- Through meeting with the same team that participated in phase 2, the result is obtained by consensus of the members of the team; or

- Through the distribution of the form for surveying the performance to the team, each member will have to evaluate and to mark the level of performance for the organization for each requirement in the form. The form is returned to the researcher for calculations and analyses.

\subsubsection{Phase 5: data analysis and interpretation}

The analysis of the data will be performed by obtaining the results of the two forms; the product of the local priority values for each requirement, obtained by the AHP method, and of the percentile values obtained by the performance survey form is performed. The values of total performances, obtained by a summatory of the products, will be analyzed according to the procedure described above for each organization, comparing and interpreting these values and the values of each requirement.

\subsubsection{Phase 6: elaboration of the conclusion report}

In this phase, the synthesis of the results containing the global percentage of performance obtained for each evaluated organization and the values obtained for each requirement evaluated in these organizations will be presented by the researcher. These results will be followed by commentaries concerning the observation of strong points and chances of improvements for the requirements that were more evident in the evaluation, this is an indicative of where the organization must be strengthen to improve its global performance.

\subsection{Hierarchic structure of the requirements}

The hierarchic structure of the requirements is obtained in phase 1 of the proposed method and has the main purpose of promoting a distribution of the requirements in criteria and subcriteria; creating, therefore, a hierarchy to evaluate the importance of each requirement for the performance of the organization.

Hence, Figure 4 presents the hierarchic structure for the performance evaluation of the organizations that will be evaluated in this work. 


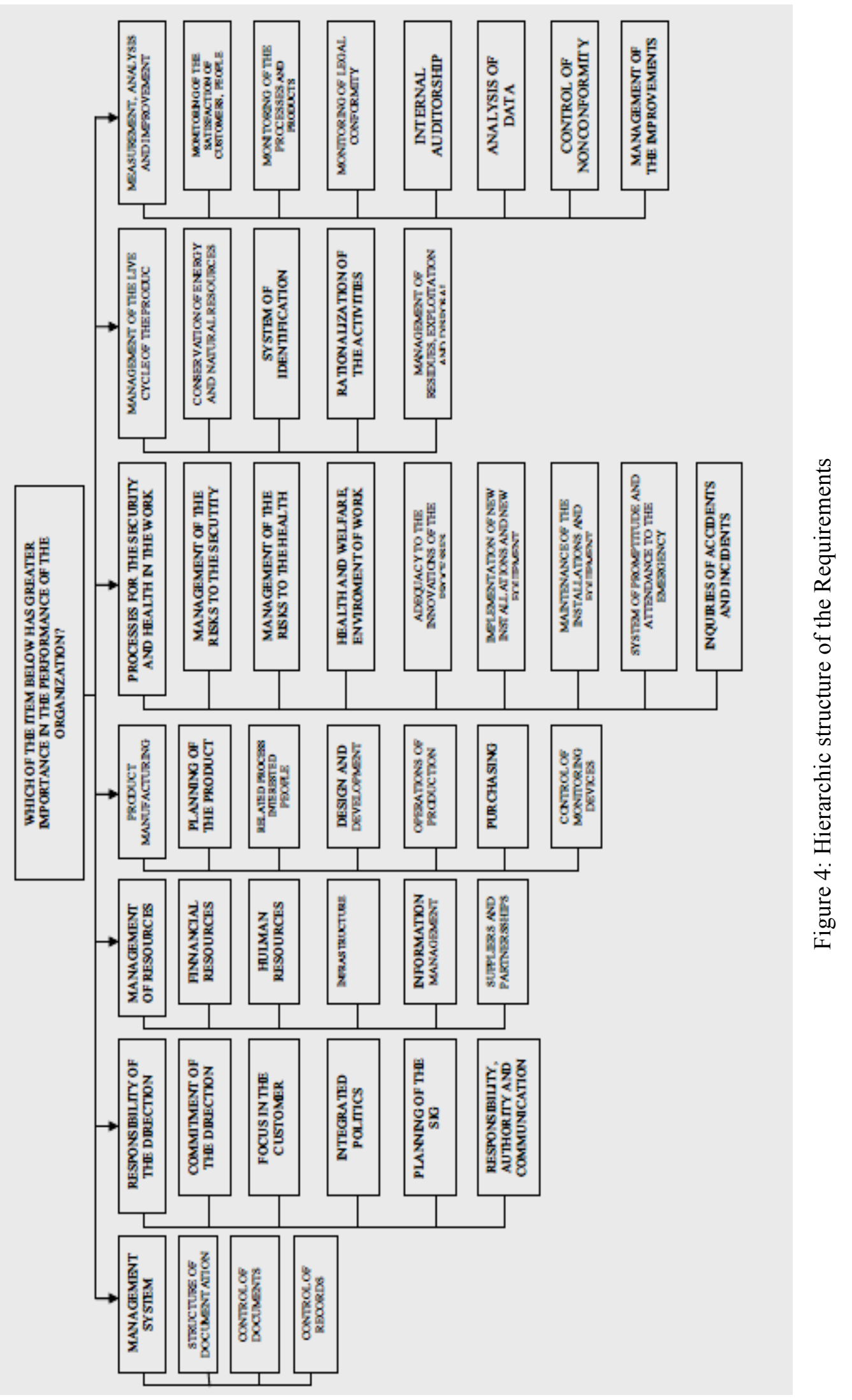


The objective, indicated in the superior box of the hierarchic structure represents the question we wish to solve, and it is generally filled with a question. For the present work, the question we wish to know or to decide is related to the organization performance. Therefore, the question was formulated in order to discover which of the requirements or items possess greater importance to the performance of an organization.

The criteria are indicated in the boxes right below the objective. For the present work, the criteria are the highest level requirements based on quality, environment and occupational health and safety management systems, its respective norms, prizes and specific methods of evaluations, and also the evaluation method of the ISO 9004:2000 annex.

The subcriteria are the unfolding of the criteria and are indicated by the boxes below the criteria. In the same way as the criteria, the subcriteria are also based on quality, environment and occupational health and safety management systems, its respective norms, prizes and specific methods of evaluations, and also the evaluation method of the ISO 9004:2000 annex.

\subsection{Important characteristics of the criteria}

This topic presents a summary of what it each criterion means, with the purpose of facilitating and harmonizing the understanding of the concepts:

- Management system: the management system is supported by the following subcriteria: documentation structure, document control and record control. This criterion allows evaluating the form in which the organization manages its management system through the processes that involve its documentation;

- Management responsibility: this criterion evaluates the involvement and the participation of the higher management of the organization in the development and maintenance of the integrated quality management system, environment and occupational health and safety of the organization, aiming at the promotion of optimum performance of its processes;

- Resource management: this criterion aims at evaluating the way by which the organization manages its human and financial resources, infrastructure, information and its relationship with suppliers and partners, aiming at a better use of these resources for continuous improvement of its processes and performance;

- Product manufacturing: this criterion aims at evaluating how the organization manages its manufacturing processes, starting at the creation of the product, continuing at operation aiming at the satisfaction of the parts interested in the excellent performance of the organization;

- Processes for occupational health and safety: this criterion evaluates how the organization treats the occupational health and safety of its employees and third parts, and it also evaluates the improvement of quality of life of these people;

- Product lifecycle management: this criterion evaluates if the organization uses the information deriving from the analysis of the product lifecycle to improve its manufacturing processes, giving subsidies for the global strategies of the organization;

- Measurement, analysis and improvement: this criterion examines how the organization manages its evaluation and monitoring methods, also the monitoring of legal conformity. This criterion also evaluates the improvement management of all the organization. 


\section{Application of the proposed method}

\subsection{General considerations}

The necessity of evaluating organizations by means of a simple and flexible method has been the main focus of this work, in the context of the integrated management system.

Therefore, in this context, the proposal of an evaluation method based on the AHP method and on the self-evaluation method of the annex of the ISO 9004:2000, proposing criteria supported and established by means of a theoretical base and a measurement system in which the importance and the behavior of the organizations is evaluated based on these criteria, is the purpose of this work.

Hence, an application of the proposed method in organizations that possess similar necessities in relation to the integrated management systems, due to the search of its performance maintenance and improvement in the national and international enterprise scene, is necessary in order to obtain real data to prove the effectiveness of this method.

It is important to emphasize the method validity to potentialize its application for the diagnosis of the organization performance and contribute for the decision making process, having as objective the continuous improvement of its processes and of the implemented management system, being this system integrated or not.

\subsection{Choosing the organizations}

The main objective of the application was to verify the effectiveness of the proposed method. Therefore, a practical validation that considered the elements such as: the complexity and the implemented management systems. Therefore, in order to apply the method, the following was considered:

- The organizations must have quality, environment and occupational health and safety management systems implemented or being implemented, this could be integrated or partially integrated;

- The people who participated in the evaluation process must know the management systems and the norms related to these systems.

- The organizations must be available for a meeting or for filling in the evaluation forms of the proposed method.

Amongst the organizations analyzed for the complete application of the proposed method, two presented favorable conditions, that is, they possess quality, environment and occupational health and safety management systems integrated or the integration was in a well structured phase. Two organizations in the transformation sector were identified: a state-owned nuclear fuel company and an auto parts and railroad sector company.

\section{Results and discussion}

Here, the results obtained with the application of the proposed method in each organization will be presented. In order to do this, the organizations will be identified in an easy way and without compromising the secrecy agreement. The organizations will be called Organization A and Organization B.

The difference between one organization and the other is how long their integrated management system has been implemented. 


\subsection{Organization A}

This organization has had an integrated management system for one year. Initially this organization had implemented the quality management system based on ISO 9001 norm for ten years.

The application of the method in the Organization initiated with a meeting between the researcher and the members of the quality, environment and occupational health and safety management coordinations in the site in which these systems were implemented. In this meeting the proposed method was explained and, after that, the punctuation of the judgments matrices was performed, as shown in Table1. A consensus among the participants was always obtained in order to fill in these matrices.

Table 1

Main judgment matrix for Organization A

\begin{tabular}{|l|c|c|c|c|c|c|c|c|}
\hline & $\begin{array}{l}\text { MANAGEMENT } \\
\text { SYSTEM }\end{array}$ & $\begin{array}{l}\text { MANAGEMENT } \\
\text { RESPONSIBILITY }\end{array}$ & $\begin{array}{l}\text { RESOURCE } \\
\text { MANAGEMENT }\end{array}$ & $\begin{array}{l}\text { PRODUCT } \\
\text { MANUFACTURING }\end{array}$ & $\begin{array}{l}\text { PROCESSES } \\
\text { FOR THE } \\
\text { OCCUPATIONAL } \\
\text { HEALTH AND } \\
\text { SAFETY }\end{array}$ & $\begin{array}{l}\text { PRODUCT } \\
\text { LIFECYCLE } \\
\text { MANAGEMENT }\end{array}$ & $\begin{array}{l}\text { MEASUREMENT, } \\
\text { ANALYSIS AND } \\
\text { IMPROVEMENT }\end{array}$ & $\begin{array}{l}\text { RELATIVE } \\
\text { PRIORITIES }\end{array}$ \\
\hline $\begin{array}{l}\text { MANAGEMENT } \\
\text { SYSTEM }\end{array}$ & 1 & 1 & 1 & $1 / 2$ & 2 & $1 / 2$ & 1 & 0.126 \\
\hline $\begin{array}{l}\text { MANAGEMENT } \\
\text { RESPONSIBIITY }\end{array}$ & 1 & 1 & 2 & 1 & 2 & 1 & 1 & 0.166 \\
\hline $\begin{array}{l}\text { RESOURCE } \\
\text { MANAGEMENT }\end{array}$ & 1 & $1 / 2$ & 1 & $1 / 2$ & 1 & $1 / 2$ & 2 & 0.118 \\
\hline $\begin{array}{l}\text { PRODUCT } \\
\text { MANUFACTURING }\end{array}$ & 2 & 1 & 2 & 1 & 2 & 2 & 1 & 0.204 \\
\hline $\begin{array}{l}\text { PROCESSES FOR } \\
\text { THE } \\
\text { OCCUPATIONAL } \\
\text { HEALTH AND } \\
\text { SAFETY }\end{array}$ & $1 / 2$ & $1 / 2$ & 1 & $1 / 2$ & 1 & 1 & 1 & 0.102 \\
\hline $\begin{array}{l}\text { PRODUCT } \\
\text { LIFECYCLE } \\
\text { MANAGEMENT }\end{array}$ & 2 & 1 & 2 & $1 / 2$ & 1 & 1 & 1 & 0.155 \\
\hline $\begin{array}{l}\text { MEASUREMENT, } \\
\text { ANALYSIS AND } \\
\text { IMPROVEMENT }\end{array}$ & 1 & 1 & $1 / 2$ & 1 & 1 & 1 & 1 & 0.128 \\
\hline
\end{tabular}

In Figure 5, it is observed through sensitivity analysis that for state-owned company, the criterion/requisite product manufacturing was considered the most important with index 0.20 , having as the most important subcriteria production operation, with index 0.048 , the one that represents the reality of this company. If the index of the requisite/criterion is increased by 0.03 , the most important subcriteria would be project and development.

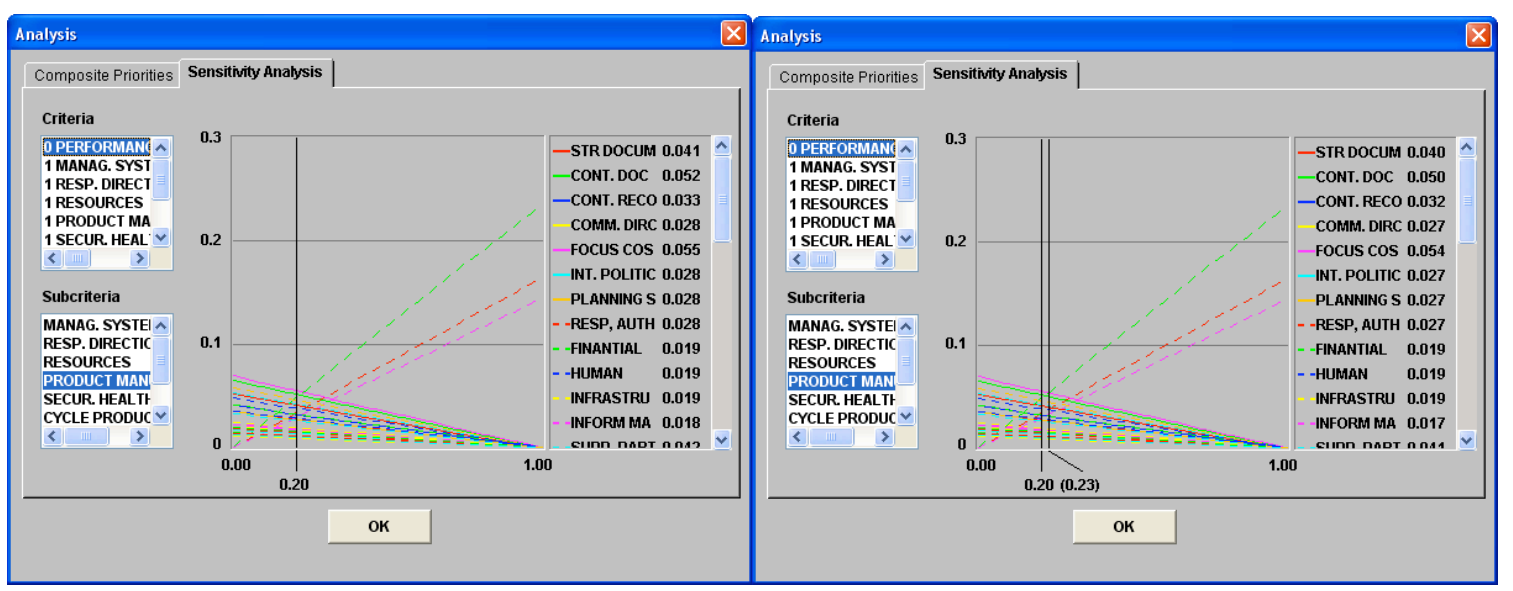

Figure 5: Analysis of sensitivity for the Organization A, by Web-Hipre software version 1.22. 
The application of the evaluation form of the criteria level of performance was given by means of interviews with the same members of the team that participated of the initial application process of the proposed method. The values obtained for each punctuation were registered and the final result was obtained by means of the calculation of the arithmetic mean of the registered values.

Table 2 presents the values obtained in the evaluation of the Organization for the criteria, subcriteria and general performance of this organization.

Table 2

Performance Result for Organization A

\begin{tabular}{|c|c|c|c|}
\hline Requirements & \multicolumn{3}{|c|}{ Results } \\
\hline \multirow{2}{*}{ Management system } & $\mathrm{AHP}$ & Level & Performance \\
\hline & 0.127 & & 0.0679 \\
\hline 1. Documentation structure & 0.018 & 0.75 & 0.0138 \\
\hline 2. Document control & 0.084 & 0.50 & 0.0420 \\
\hline 3. Record control & 0.024 & 0.50 & 0.0120 \\
\hline \multirow{3}{*}{ Management responsibility } & \multicolumn{3}{|c|}{ Results } \\
\hline & $\mathrm{AHP}$ & Level & Performance \\
\hline & 0.166 & & 0.11885 \\
\hline 4. Commitment of the direction & 0.057 & 0.75 & 0.04297 \\
\hline 5. Focus in the custumer & 0.041 & 0.75 & 0.03060 \\
\hline 6. Integrated politics & 0.045 & 0.75 & 0.03382 \\
\hline 7. Planning of the SIG & 0.010 & 0.50 & 0.00485 \\
\hline 8. Responsibility, authority and communication & 0.013 & 0.50 & 0.00660 \\
\hline \multirow{3}{*}{ Resource management } & \multicolumn{3}{|c|}{ Results } \\
\hline & AHP & Level & Performance \\
\hline & 0.118 & & 0.0684 \\
\hline 9. Financial resources & 0.034 & 0.50 & 0.0171 \\
\hline 10. Human resousces & 0.037 & 0.75 & 0.0280 \\
\hline 11. Infrastructure & 0.012 & 0.50 & 0.0060 \\
\hline 12. Information management & 0.014 & 0.50 & 0.0068 \\
\hline 13. Suppliers and partnerships & 0.021 & 0.50 & 0.0105 \\
\hline \multirow{3}{*}{ Product manufacturing } & \multicolumn{3}{|c|}{ Results } \\
\hline & $\mathrm{AHP}$ & Level & Performance \\
\hline & 0.204 & & 0.1399 \\
\hline 14. Planning of the product manufacturing & 0.036 & 0.75 & 0.0271 \\
\hline 15. Related processes the interested people & 0.039 & 0.50 & 0.0193 \\
\hline 16. Design and development & 0.048 & 0.75 & 0.0357 \\
\hline 17. Operations of production & 0.048 & 0.75 & 0.0363 \\
\hline 18. Purchasing & 0.011 & 0.50 & 0.0057 \\
\hline 19. Control of monitoring devices & 0.021 & 0.75 & 0.0156 \\
\hline \multirow{3}{*}{ Processes for the occupational health and safety } & \multicolumn{3}{|c|}{ Results } \\
\hline & AHP & Level & Performance \\
\hline & 0.102 & & 0.0655 \\
\hline 20. Management of the risks to the safety & 0.020 & 0.75 & 0.0152 \\
\hline 21. Magement of the risks to the health & 0.015 & 0.75 & 0.0111 \\
\hline 22. Health and welfare, environment of work & 0.015 & 0.50 & 0.0076 \\
\hline 23. Adequancy to the innovations of the processses & 0.011 & 0.50 & 0.0054 \\
\hline 24. Implematation of new installations and new equipment & 0.009 & 0.75 & 0.0065 \\
\hline 25. Maintenance of the installations and equipment & 0.006 & 0.50 & 0.0031 \\
\hline 26. System of promptitude and attendance to the emergency & 0.014 & 0.75 & 0.0103 \\
\hline 27. Inquiries of accidents and incidents & 0.012 & 0.50 & 0.0061 \\
\hline
\end{tabular}


Table 2: Continued

\begin{tabular}{|l|l|l|l|}
\hline \multirow{2}{*}{ Management of the live cycle of the product } & \multicolumn{3}{|l|}{ Results } \\
\cline { 2 - 4 } & AHP & Level & Performance \\
\cline { 2 - 4 } & 0.154 & & 0.0862 \\
\hline 28. Conservation of energy and natural resources. & 0.049 & 0.50 & 0.0243 \\
\hline 29. System of identification & 0.026 & 0.25 & 0.0064 \\
\hline 30. Rationalization of the activities & 0.018 & 0.50 & 0.0088 \\
\hline 31. Management of residues, exploitation and disposal & 0.062 & 0.75 & 0.0465 \\
\hline \multirow{3}{*}{ Measurement, analysis and improvement. } & Results & \\
\cline { 2 - 4 } & AHP & Level & Performance \\
\cline { 2 - 4 } & 0.128 & & 0.0839 \\
\hline 32. Monitoring of the satisfaction of customers and interested people & 0.018 & 0.75 & 0.0138 \\
\hline 33. Monitoring of the processes and products & 0.012 & 0.75 & 0.0087 \\
\hline 34. Monitoring of legal conformity & 0.020 & 0.75 & 0.0152 \\
\hline 35. Internal auditorship & 0.036 & 0.50 & 0.0179 \\
\hline 36. Analysis of data & 0.007 & 0.50 & 0.0034 \\
\hline 37. Control of nonconformity & 0.027 & 0.75 & 0.0200 \\
\hline 38. Management of the improvements & 0.010 & 0.50 & 0.0048 \\
\hline General performance of Organization A & $60.03 \%$ & \\
\hline
\end{tabular}

It was observed that for this organization the most important performance criterion is product manufacturing; however, its level of performance can be improved. Such fact is due when the quality management system was implemented, that is, ten years.

Within the criterion product manufacturing, the subcriteria manufacturing operation was the most important for its performance, it obtained the biggest performance amongst the other evaluated subcriteria.

The criterion processes for the occupational health and safety presented the lowest index in this performance evaluation, followed by the criterion resource management. Such fact is, according to the team responsible for the integrated management system, due to the short implantation time of the occupational health and safety management system and its integration with the quality and environmental management systems.

The general performance of the Organization A was $60.03 \%$, the value was $10 \%$ above average of the performance scale. This performance reflects the beginning of performance improvement of the organization, which will have to be strengthen to improve the criteria that presented low values.

\subsection{Organization B}

This organization does not have an integrated management system yet. Initially this organization implemented the quality management system based on ISO 9001 norm, having over ten years of implantation. The application of the method in the Organization B initiated with a meeting between the researcher and the members of the quality, environment and occupational health and safety management coordinations in the site in which these systems were implemented. In this meeting the proposed method was explained and, after that, the punctuation of the judgments matrices was performed, as shown in Table 3 . A consensus among the participants was always obtained in order to fill in these matrices. 
Table 3

Main judgment matrix for Organization B

\begin{tabular}{|l|c|c|c|c|c|c|c|c|}
\hline & $\begin{array}{l}\text { MANAGEMENT } \\
\text { SYSTEM }\end{array}$ & $\begin{array}{l}\text { MANAGEMENT } \\
\text { RESPONSIBILITY }\end{array}$ & $\begin{array}{l}\text { RESOURCE } \\
\text { MANAGEMENT }\end{array}$ & $\begin{array}{l}\text { PRODUCT } \\
\text { MANUFACTURING }\end{array}$ & $\begin{array}{l}\text { PROCESSES } \\
\text { FOR THE } \\
\text { OCCUPATIONAL } \\
\text { HEALTH AND } \\
\text { SAFETY }\end{array}$ & $\begin{array}{l}\text { PRODUCT } \\
\text { LIFECYCLE } \\
\text { MANAGEMENT }\end{array}$ & $\begin{array}{l}\text { MEASUREMENT, } \\
\text { ANALYSIM AND } \\
\text { IMPROVEMENT }\end{array}$ & $\begin{array}{l}\text { RELATIVE } \\
\text { PRIORITIES }\end{array}$ \\
\hline $\begin{array}{l}\text { MANAGEMENT } \\
\text { SYSTEM }\end{array}$ & 1 & 3 & 3 & 2 & 3 & 3 & 3 & 0.310 \\
\hline $\begin{array}{l}\text { MANAGEMENT } \\
\text { RESPONSIBIITY }\end{array}$ & $1 / 3$ & 1 & $1 / 2$ & $1 / 2$ & 1 & 2 & 1 & 0.098 \\
\hline $\begin{array}{l}\text { RESOURCE } \\
\text { MANAGEMENT }\end{array}$ & $1 / 3$ & 2 & 1 & 1 & 2 & 2 & 2 & 0.161 \\
\hline $\begin{array}{l}\text { PRODUCT } \\
\text { MANUFACTURING }\end{array}$ & $1 / 2$ & 2 & 1 & 1 & 2 & 3 & 2 & 0.179 \\
\hline $\begin{array}{l}\text { PROCESSES FOR } \\
\text { THE } \\
\text { OCCUPATIONAL } \\
\text { HEALTH AND } \\
\text { SAFETY }\end{array}$ & $1 / 3$ & 1 & $1 / 2$ & $1 / 2$ & 1 & 1 & 1 & 0.088 \\
\hline $\begin{array}{l}\text { PRODUCT } \\
\text { LIFECYCLE } \\
\text { MANAGEMENT }\end{array}$ & $1 / 3$ & $1 / 2$ & $1 / 2$ & $1 / 3$ & 1 & 1 & 1 & 0.077 \\
\hline $\begin{array}{l}\text { MEASUREMENT, } \\
\text { ANALYSIS AND } \\
\text { IMPROVEMENT }\end{array}$ & $1 / 3$ & 1 & $1 / 2$ & $1 / 2$ & 1 & 1 & 1 & 0.088 \\
\hline
\end{tabular}

In Figure 6, it is observed that for the private sector company, the most important requisite/criterion was the management system with index of 0.31 and as the most important subcriteria document control, with index of 0.136 which also represents the reality of this company. If the index of the requisite/criterion is lowered by 0.13 , the most important subcriteria would be supplying and partners.

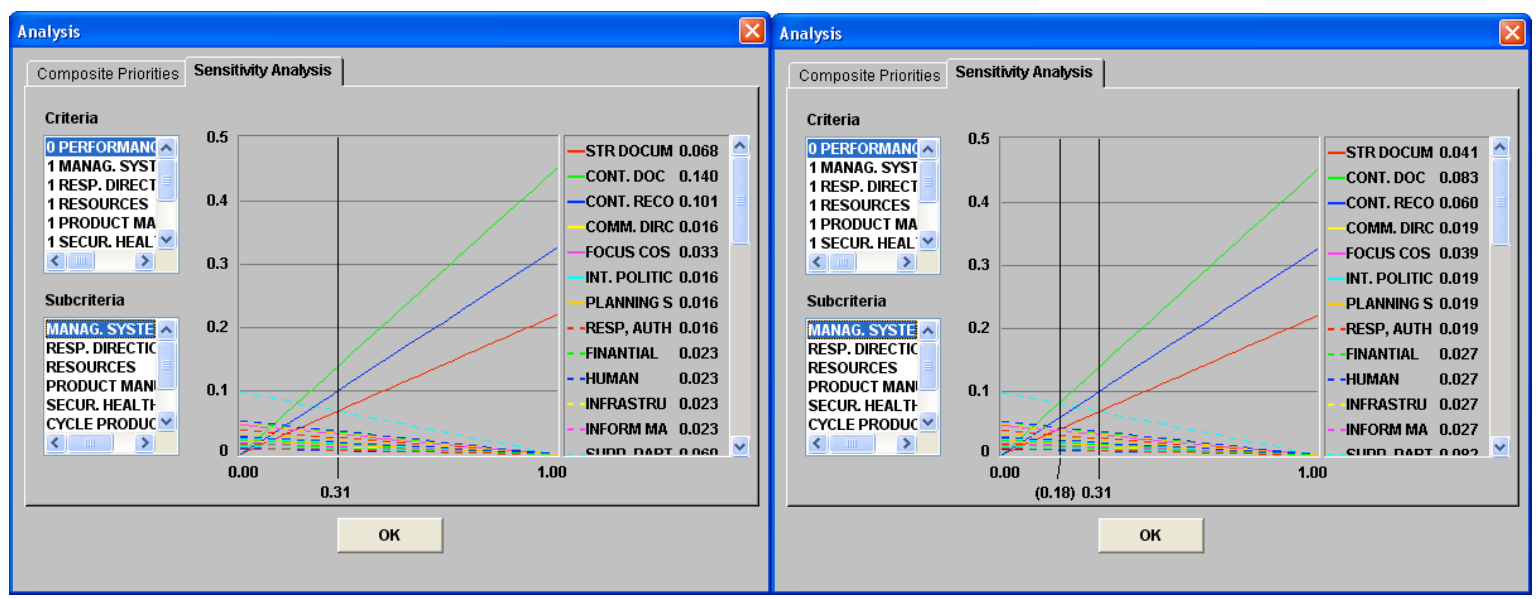

Figure 6: Analysis of sensitivity for Organization B, by Web-Hipre software version 1.22.

The application of the evaluation form of the criteria level of performance was given by distributing the forms to the same members of the team that participated of the initial application process of the proposed method. The values obtained for each punctuation were registered in the annex 1 form and the final result was obtained by means of the calculation of the arithmetic mean of the registered values.

Table 4 presents the values obtained in the evaluation of Organization B for the criteria, subcriteria and general performance of this organization. 
Table 4

Performance Result for Organization B

\begin{tabular}{|c|c|c|c|}
\hline \multirow{3}{*}{\begin{tabular}{|l|} 
Requirements \\
Management system
\end{tabular}} & \multicolumn{3}{|c|}{ Results } \\
\hline & $\mathrm{AHP}$ & Level & Performance \\
\hline & 0.310 & & 0.2327 \\
\hline 1. Documentation structure & 0.055 & 0.75 & 0.0412 \\
\hline 2. Document control & 0.136 & 0.75 & 0.1022 \\
\hline 3. Record control & 0.119 & 0.75 & 0.0893 \\
\hline \multirow{3}{*}{ Management responsibility } & \multicolumn{3}{|c|}{ Results } \\
\hline & $\mathrm{AHP}$ & Level & Performance \\
\hline & 0.098 & & 0.0363 \\
\hline 4. Management commitment & 0.022 & 0.50 & 0.0108 \\
\hline 5. Focus in the customer & 0.022 & 0.50 & 0.0108 \\
\hline 6. Integrated politics & 0.026 & 0.25 & 0.0065 \\
\hline 7. Planning of the sig & 0.013 & 0.25 & 0.0033 \\
\hline 8. Responsibility, authority and communication. & 0.010 & 0.50 & 0.0049 \\
\hline \multirow{3}{*}{ Resource management } & \multicolumn{3}{|c|}{ Results } \\
\hline & $\mathrm{AHP}$ & Level & Performance \\
\hline & 0.161 & & 0.1134 \\
\hline 9. Financial resources & 0.022 & 0.75 & 0.0593 \\
\hline 10. Human resources & 0.022 & 0.50 & 0.0235 \\
\hline 11. Infrastructure & 0.026 & 0.50 & 0.0077 \\
\hline 12. Information management & 0.013 & 0.75 & 0.0183 \\
\hline 13. Suppliers and partners & 0.010 & 0.25 & 0.0046 \\
\hline \multirow{3}{*}{ Product manufacturing } & \multicolumn{3}{|c|}{ Results } \\
\hline & $\mathrm{AHP}$ & Level & Performance \\
\hline & 0.179 & & 0.1299 \\
\hline 14. Planning of the product manufacturing & 0.024 & 0.75 & 0.0184 \\
\hline 15. Related processes the interested people & 0.037 & 0.75 & 0.0279 \\
\hline 16. Project and development & 0.031 & 0.75 & 0.0232 \\
\hline 17. Production operations & 0.046 & 0.75 & 0.0352 \\
\hline 18. Purchasing & 0.024 & 0.50 & 0.0123 \\
\hline 19. Control of monitoring devices & 0.017 & 0.75 & 0.0128 \\
\hline \multirow{3}{*}{ Processes for the occupational health and safety } & \multicolumn{3}{|c|}{ Results } \\
\hline & AHP & Level & Performance \\
\hline & 0.088 & & 0.033540 \\
\hline 20. Management of the risks to the safety & 0.016 & 0.50 & 0.0082 \\
\hline 21. Management of the risks to the health & 0.007 & 0.50 & 0.0038 \\
\hline 22. Health and welfare, environment of work. & 0.006 & 0.25 & 0.0016 \\
\hline 23. Adequacy to the innovations of the processes & 0.009 & 0.25 & 0.0022 \\
\hline 24. Implementation of new installations and new equipment & 0.010 & 0.25 & 0.0025 \\
\hline 25. Maintenance of the installations and equipment & 0.007 & 0.25 & 0.0019 \\
\hline 26. System of promptitude and attendance to the emergency & 0.024 & 0.25 & 0.0059 \\
\hline 27. Inquiries of accidents and incidents & 0.015 & 0.50 & 0.0073 \\
\hline \multirow{3}{*}{ Product life cycle management } & \multicolumn{3}{|c|}{ Results } \\
\hline & AHP & Level & Performance \\
\hline & 0.077 & & 0 \\
\hline 28. Conservation of energy and natural resources. & 0.010 & 0 & 0 \\
\hline 29. System of identification and labeling & 0.024 & 0 & 0 \\
\hline 30. Rationalization of the activities & 0.010 & 0 & 0 \\
\hline 31. Management of residues, exploitation and disposal & 0.013 & 0 & 0 \\
\hline
\end{tabular}


Table 4: Continued

\begin{tabular}{|l|l|l|l|}
\hline \multirow{2}{*}{ Measurement, analysis and improvement } & \multicolumn{2}{l|}{ Results } \\
\cline { 2 - 4 } & AHP & Level & Performance \\
\cline { 2 - 4 } & 0.088 & & 0.0517 \\
\hline 32. Monitoring of the satisfaction of customers and interested people & 0.012 & 0.75 & 0.0089 \\
\hline 33. Monitoring of the processes and products & 0.012 & 0.75 & 0.0104 \\
\hline 34. Monitoring of legal conformity & 0.017 & 0.75 & 0.0127 \\
\hline 35. Internal auditorship & 0.008 & 0.75 & 0.0057 \\
\hline 36. Analysis of data & 0.010 & 0.50 & 0.0049 \\
\hline 37. Control of nonconformity & 0.010 & 0.50 & 0.0051 \\
\hline 38. Management of the improvements & 0.008 & 0.50 & 0.0038 \\
\hline General performance of Organization B & $\mathbf{5 9 . 5 4 \%}$ & \\
\hline
\end{tabular}

It was observed that for this organization the most important performance criterion the management system, with a good level of performance, but it can still be improved. Such fact is due to when the quality management system has been implemented in the Organization, over ten years.

Within the management system criterion in Organization B, the most important for its performance was the subcriteria document control, which obtained the biggest performance amongst the other evaluated subcriteria.

The criterion product lifecycle management presented the lowest index in this performance evaluation, followed by the criterion processes for occupational health and safety. Such fact is, according to the team responsible for the management system, because the environment and occupational health and safety management systems are being implemented at the moment with the purpose of improving the quality management systems already implemented.

The general performance of Organization B was of 59.54\%, a value above average in the performance scale. This performance reflects the need for the implementation of environmental and occupational health and safety systems with the purpose of improving the performance of the organization as a whole.

\section{Conclusions}

The results presented demonstrated that the proposed method is an efficient tool to diagnose, in a simple and flexible way, the performance of an organization that implemented or is implementing a quality, environment and occupational health and safety management systems with the purpose of improving the performance of its internal productive processes or of administrative support. The two organizations presented similar levels of performance.

The characteristic elements and evaluation procedures were based on the Annex of norm ISO 9004:2000, on the AHP method and on theory gave the support to the context of this work.

The characteristic elements of evaluation procedures in other areas of study were identified after elaboration and application of the proposed method in organizations.

The criteria, items and requirements that allowed the evaluation of the organizations that participated in these work were defined with the purpose of giving a support to decision making strategies that can lead these organizations to achieve a platform excellence in their respective areas of performance.

\section{REFERENCES}

ABNT NBR ISO 14001, Sistemas de gestão ambiental - Requisitos. Dez. 2004.

ABNT NBR ISO 9001, Sistemas de gestão da qualidade - Requisitos. Dez. 2000. 
ABNT NBR ISO 9004, Sistemas de gestão da qualidade - Diretrizes para melhorias de desempenho. Dez. 2000.

Cerqueira, J. P. Sistemas de gestão integrados: ISO 9001, ISO 14001, NBR 16001, OHSAS 18001, SA 8000: Conceitos e aplicações. - Rio de Janeiro: Qualitymark, 2006.

Corrêa. A. A. Avaliação de um sistema integrado de gestão: um estudo na indústria automotiva. Dissertação (Mestrado em Engenharia). UFRS, Porto Alegre, RS. 2004.

De Cicco, F. OHSAS 18001 - Especificação para sistemas de gestão da segurança e saúde no trabalho - QSP - 2003.

De Cicco, F. SIGs - Sistemas integrados de gestão. Da teoria à prática-QSP, 2003.

Forman, E.; Selly, M. Decisions by objectives. Expert Choice, Inc.(2001). Disponível em $<$ http://www.expertchoice.com/service/books/dbo.html>, acesso em desembro de 2008.

Gomes, L. F. A. M.; et al. Tomada de decisões em cenários complexos: introdução aos métodos discretos do apoio multicritério à decisão. São Paulo. Ed. Thomson Learning, 2004.

Jorgensen, T. H.; Remmen, A.; Mellado, M. D. Integrated management systems - three diferrent levels of integration. - Journal of Cleaner Prodction. 2006.

Karapetrovic, S. Strategies for the integration of management systems and standards. - The TQM Magazine. Vol. 14, n. ${ }^{\circ}$ 1, pp. 61-67. 2002.

Luz, S. O. C.; Sellitto, M; Gomes, L. P. Medição de desempenho ambiental baseada em método multicriterial de apoio à decisão: Estudo de caso na indústria automotiva. Revista Gestão e Produção, v. 13, n3, p. 557-570, set.-dez. 2006.

Saaty, T. L. Analytic Hierarchy Process, vol. 2 Decision Making for Leaders. Vol. II of the AHP Series Thomas L. Saaty, 315 pp., RWS Publ. (new ed.), 2001.

Saaty, T. L. Relative Measurement and Its Generalization in Decision Making. Why Pairwise Comparisons are Central in Mathematics for the Measurement of Intangible Factors. The Analytic Hierarchy/Network Process. Rev. R. Acad. Cien. Serie A. Mat.VOL. 102 (2), 2008, pp. 251-318.

Salomon , V. A. P. Desempenho da Modelagem do Auxílio à Decisão por Múltiplos Critérios na Análise do Planejamento e Controle da Produção. Tese (Doutorado em Engenharia), Poli/USP, São Paulo, SP, 2004.

Shimizu, T. Decisão nas Organizações: introdução aos problemas de decisão encontrados nas organizações e nos sistemas de apoio à decisão. São Paulo. Ed. Atlas. 2006.

Wilkinson, G. and Dale, B. G. Integrated management system: an examination of the concept and theory. The TQM Magazine. Vol. 11, n. ${ }^{\circ}$ 2, pp. 95-104. 1999. 